\title{
The Study of Food-Grade Induced Expression and Enzymatic Properties of L-Arabinose Isomerase from Lactobacillus plantarum WU14 with High D-Tagatose Yield
}

\author{
Xiaoyu Chang, Bi Ying, Yanli Zhang, Huifang Cao, Tong Zhou, Ping'an Zhong, Bo Xu* \\ Jiangxi Engineering Laboratory for the Development and Utilization of Agricultural Microbial Resources, College \\ of Bioscience and Bioengineering, Jiangxi Agricultural University, Nanchang, China \\ Email: *xubo583@sina.com
}

Received 11 March 2016; accepted 25 April 2016; published 28 April 2016

Copyright $@ 2016$ by authors and Scientific Research Publishing Inc.

This work is licensed under the Creative Commons Attribution International License (CC BY).

http://creativecommons.org/licenses/by/4.0/

(c) (1) Open Access

\section{Abstract}

L-arabinose isomerase (L-AI) is the key enzyme for D-galactose isomerization of D-tagatose by biological method. In this research, Lactobacillus plantarum WU14 with high D-tagatose yield was identified as Lactobacillus plantarum was isolated from the number of lactic acid bacteria from pickled vegetables. The crude L-arabinose isomerase activity of Lactobacillus plantarum WU14 with high D-tagatose yield was $13.95 \mathrm{U} / \mathrm{mL}$ under the optimal temperature $60^{\circ} \mathrm{C}$, $\mathrm{pH} 7.17$ and substrate concentration $0.8 \mathrm{~mol} / \mathrm{L}$, and the conversion rate of $56.12 \%$ could be gained after 28 hours. Protein structure and specific of L-Arabinose Isomerase of Lactobacillus plantarum WU14 were researched. The results showed that $\mathrm{L}$-arabinose isomerase is mainly composed of alpha helix and random coil. Then the recombinant L-AI gene was inserted into the food-grade expression vector pRNA48 and expressed in L. lactis NZ9000 successfully. The target protein expression reached the maximum amount when the induced concentration of nisin reaches $30 \mathrm{ng} / \mathrm{mL}$ after $12 \mathrm{~h}$. And the crude enzyme activity of recombinant bacteria reached $6.21 \mathrm{U} / \mathrm{mL}$ under $60^{\circ} \mathrm{C}$. Otherwise the optimal conversion rate recombinant of $L$. lactis NZ9000/pRNA48-L-AI can reach $39.21 \%$ under the temperature of $50^{\circ} \mathrm{C}$, $\mathrm{pH} \mathrm{7.17}$ and $\mathrm{D}$-galactose concentration was $0.6 \mathrm{~mol} / \mathrm{L}$.

\section{Keywords}

D-Tagatose, Lactobacillus plantarum WU14, L-Arabinose Isomerase, Recombinant PCR Technology, Food-Grade Expression

\footnotetext{
${ }^{*}$ Corresponding author.
}

How to cite this paper: Chang, X.Y., Ying, B., Zhang, Y.L., Cao, H.F., Zhou, T., Zhong, P.A. and Xu, B. (2016) The Study of Food-Grade Induced Expression and Enzymatic Properties of L-Arabinose Isomerase from Lactobacillus plantarum WU14 with High D-Tagatose Yield. Food and Nutrition Sciences, 7, 320-337. http://dx.doi.org/10.4236/fns.2016.74034 


\section{Introduction}

D-tagatose is a kind of six carbon ketone sugar which existed relatively rare in nature. It's not only the isomers of D-galactose but also the epimer at C-4 site of D-fructose. Academic world called this kind of monosaccharide which existed relatively rare in nature the rare sugar [1]. The formula weight and melting point of it are $180.6^{\circ} \mathrm{C}$ and $132^{\circ} \mathrm{C}$ to $135^{\circ} \mathrm{C}$ respectively, and it also has the resistance of heat, acid and alkali. Not only the sweetness of it presents $92 \%$ comparing to the sucrose but also the sweet characteristics is similar to it, but the only $1 / 3$ heat of the sucrose was generated [2]. It's one kind of food filling type sweeteners with low energy and the mulriple function including the inhibition of high blood sugar, improving the intestinal flora, resisting to tooth decay, promoting the blood health, the enhancement of cellular sensitivity to the toxin and inhibiting toxin like cocaine and nitrofurantoin to hurt liver cells significantly which are important to our daily life [3] [4]. FDA in America approves D-tagatose can be used in food as GRAS on April 11, 2001. At present, D-tagatose as a kind of low caloric sweeteners is used widely in comfit, beverage, healthy food, and nutritional products in South Korea, Australia, New Zealand and the United States [5]. Besides that D-tagatose as the sweeteners has some special functions in relieving symptoms of II diabetes and preventing obesity [6] [7]. In addition, the production of D-tagatose can be composited by prebiotics which attracted broad attention of the many commercial investors because of the reasons given above these days. Joint FAO/WHO Expert Committee on Food Additives approved D-tagatose can be regarded as food additives which ADI was $0.80 \mathrm{mg} / \mathrm{kg} \cdot \mathrm{d}$ in June 2001 [1].

D-tagatose as one kind of rare sugar is usually produced by using chemical or biological processes [8]. The method of chemical catalytic mainly uses galactose as raw materials through the isomerization and acid neutralization these two steps to implement the transform [9]. And the United States patent of producing D-tagatose applied by Beadle etc. mentioned that D-tagatose was produced by the derivative of the chemical reaction which produced by calcium catalyst catalyze the hydrolysis of lactose. But the chemical reaction process has some disadvantages, such as the complex purification steps, the low yield of D-tagatose and the by-products produced by the reaction process which is difficult to separate and result in much more difficulties of the purification in downstream process the funds, whereas the chemical waste also affect the surrounding environment [9]. Thus it can be seen, the biological conversion with low energy has certain competitive advantages not only in the processes but also in cost and production sides and can protect environment well.

The production of D-tagatose by biological conversion was described by Izumori et al. in 1984 the first time. They have reported that several kinds of microbes have the activity of galactitol dehydrogenase and can produce D-tagatose by oxidizing galactitol such as Arthrobacterium, Mycobacterium tuberculosis and Enteric bacilli [10]-[13]. According to the method, we can get $18.4 \mathrm{~g} / \mathrm{L}$ of D-tagatose from $20 \mathrm{~g} / \mathrm{L}$ of D-galactose and the conversion efficiency reached $92 \%$. Because of the high cost of raw materials of galactose alcohol, this method has not been put into the large-scale production of D-tagatose [10]-[13]. Soon later, Cheetham utilized the L-arabinose isomerase in lactic acid bacteria to transform D-galactose to D-galactose with the low cost galactitol for the first time [14]. Because of lactic acid bacteria being probiotics and the certain potential which L-AI can transform to D-galactose, this method can be researched deeply in the future.

These years, the progresses on the bioproduction of D-tagatose focuse on utilizing L-AI enzymic method and using strain fermentation process to transform D-galactose to D-tagatose. The priority field of L-AI is the screening of the strain which enzyme production quantity is high, and it is suitable for mass production, and building up L-AI expression system, researching the appropriate process of enzyme production and fermentation. Nowadays, the strains which can use L-AI to produce D-tagatose included Escherichia coli, Thermotoga neapolitana, Geobacillus stearothermophilus, Geobacillus thermodenitrificans, Thermus sp, Thermoanaerobacter mathranii, Thermotoga maritime, Bacillus stearothermophilus US100 and Lactic acid bacteria etc. [15]-[22]. $\mathrm{PH}$ of the growth conditions for lactic acid bacteria and the lactose hydrolysate are the same, so that it can save cost and is easy to operate.

Since L-arabinose isomerase is used in the study of D-tagatose production, the research content is so broad that covers almost the whole of enzyme engineering research content, but there are still some shortcomings in the research of L-AI. First of all, most of the strains' enzyme activities are low and the product must be further metabolized in the later period which due to low convert ratio. Secondly, genetically modified L-AI is short of precise and powerful crystal structure data so that only depending on the result to speculate the differences between the amino acid sequences is adverse to improve the reaction activity, the thermal stability, optimal pH and the ability of the combination to the substrate of the enzyme. Finally, it has non-significant advances in the 
research of L-AI food-grade probiotics strains and it hinders the mass industrial production of the D-tagatose. The toxoid produced along with the progress is also a problem in using E. coli as the host so the establishment of L-AI food-grade probiotics strains is the hotspot for industrial production and application research of this enzyme.

This article started from the source of strain, we screened out Lactobacillus plantarum WU14 which was probiotics with high D-tagatose yield from pickles and pickled vegetables and we analyzed the enzyme activity, gene and bioinformatics of L-AI. Then we designed inside and outside specific primers by recombinant PCR to removal of enzyme locus which related with food-grade expression vector of L-AI gene, and then electric transfered the recombinant vector into L. lactis NZ9000 cells. Finally we obtained the recombinant bacteria L. lactis NZ9000/pRNA48-L-AI, and implemented the food-grade inducible expression of L-AI gene in Lactococcus lactis.

\section{Materials and Methods}

\subsection{Materials}

\subsubsection{Strains, Plasmids, and Main Biochemical Reagents}

After concentrated strains by MRS culture medium and gradient dilution, we isolated test strains from pickles and sauerkraut. E. coli $\mathrm{DH} 5 \alpha$ preserved by our laboratory through bromocresol purple solid MRS culture medium, D-galactose is bought from Lanji technology development company in shanghai, D-tagatose standard is bought from Sigma company, pGEM-T vector is bought from Promega company, T4 DNA ligase is bought from Takara company, DNA recovery kit is bought from TransGen Biotech, L. lactis NZ9000 (preserved in our laboratory), L. lactis NZ9000/pRNA48 (preserved in our laboratory), DNA Marker, Protein molecular weight standards, dNTP, TaqDNA polymerase, restriction enzymes, pure Midi Plasmid Kit is bought from TANGEN biotech company, Wizard DNA Clean-Up System is bought from promega company, synthesising PCR primers and sequencing are accomplished by Sangon Biotech company.

\subsubsection{Laboratory Equipment}

PCR-Cycler (Biometra in German), UV transilluminator (UVP in America), Intelligent table top refrigerated centrifuge (Eppendorf Company in German, Centrifuge 5804R), autoclave (Shanghai HUAXIAN Medical Nuclear Instruments Company), HH type electric-heated thermostatic water bath (Zhongda instrument plant in Jiangsu jintan), VD-650 table type (vertical) on clean bench (Suzhou Zhijing Purification Equipment company), JY99-2D ultrasonic cell crusher (Ningbo Xingzhi Biotechnology Company, LTD), 723 VIS Spectrophotometer (Shanghai Youke instrument company).

\subsubsection{Culture Medium and the Commonly Used Solution}

MRS culture medium (g/L): peptone $10 \mathrm{~g}$, beef extract $10 \mathrm{~g}$, yeast extract $5 \mathrm{~g}, \mathrm{~K}_{2} \mathrm{HPO}_{4} 2 \mathrm{~g}$ ammonium citrate 2 g, anhydrous sodium acetate $5 \mathrm{~g}$, glucose $20 \mathrm{~g}$, polysorbate $801.0 \mathrm{~mL}, \mathrm{MgSO}_{4} \cdot 7 \mathrm{H}_{2} \mathrm{O} 0.5 \mathrm{~g}$ and $0.25 \mathrm{~g} \mathrm{MnSO}_{4}$. $2 \mathrm{H}_{2} \mathrm{O}$, to $\mathrm{pH}$ 7.0; Plate filter medium: MRS culture medium adding 2\% AGAR and $0.01 \mathrm{~g} / \mathrm{L}$ bromocresol purple; Fermentation medium (g/L): yeast extract $10 \mathrm{~g}$, peptone $10 \mathrm{~g}$, glucose $2.5 \mathrm{~g}$, anhydrous sodium acetate $10 \mathrm{~g}$, $\mathrm{MgSO}_{4} \cdot 7 \mathrm{H}_{2} \mathrm{O} 0.4 \mathrm{~g}$ and $\mathrm{MnSO}_{4} \cdot 2 \mathrm{H}_{2} \mathrm{O} 0.05 \mathrm{~g}, \mathrm{~K}_{2} \mathrm{HPO}_{4} 0.4 \mathrm{~g}$, L-Arab sugar $5 \mathrm{~g}$ to $\mathrm{pH}$ 7.0.; GEL1 medium: tryptone $20 \mathrm{~g}$, sugar $5 \mathrm{~g}$, yeast extract $5 \mathrm{~g}$, sodium chloride $4 \mathrm{~g}$, gelatin $2.5 \mathrm{~g}$, sodium acetate $1.5 \mathrm{~g}$, glucose $10 \mathrm{~g}$, ascorbic acid $0.5 \mathrm{~g}$, lactose $5 \mathrm{~g}$ and distilled water to $1000 \mathrm{ml}$, adjust $\mathrm{pH}$ value to 6.8 , and high pressure to sterilize; GM17 medium: plant peptone $5.0 \mathrm{~g}$, peptone $5.0 \mathrm{~g}$, beef extract $2.5 \mathrm{~g}$, beta glycerol phosphate disodium $19 \mathrm{~g}$, yeast extract $5.0 \mathrm{~g}$, ascorbic acid $0.5 \mathrm{~g}, \mathrm{MgSO}_{4} \cdot 7 \mathrm{H}_{2} \mathrm{O} 0.25 \mathrm{~g}$ and glucose $5 \mathrm{~g}$, added distilled water to $1000 \mathrm{ml}$, adjust $\mathrm{pH}$ value to $7.1,108^{\circ} \mathrm{C}$ sterilize $20 \mathrm{~min}$; LB liquid medium; LB solid medium (containing ampicillin 100 ug/mL, IPTG, X-gal); $0.2 \mathrm{~mol} / \mathrm{L}$ potassium phosphate buffer (pH 7.0), $0.1 \mathrm{~mol} / \mathrm{L}$ hydrochloric acid terminated reaction liquid.

\subsection{Methods}

\subsubsection{Preliminary Screening the Lactobacillus Producted D-Tagatose}

Put moderate samples from pickles and pickled vegetables into the $100 \mathrm{ml}$ enrichment medium which containing bromocresol purple ( $250 \mathrm{ml}$ conical flask), and after standing to cultivate for 24 hours at $37^{\circ} \mathrm{C}$, transfer $1 \mathrm{ml}$ of bacteria liquid into fresh enrichment medium with bromocresol purple. Repeat several times like this. Choose 
the conical flasks with nutrient solution which color change from purple to yellow, culture will be diluted to appropriate ratio $\left(10^{-8}-10^{-9}\right)$, and $1 \mathrm{ml}$ diluent will be smeared on MRS solid tablet. Observe and pick the colone which can change the bromocresol from purple to yellow and have the soluble calcium circle. Layout it to purify further until the color, size, shape of strains become the same and observed them by Gram staining method and preserved by $40 \%$ glycerinum finally. Preserve triplicate of each strain and mark them well.

\subsubsection{Activate Lactobacillus with High D-Tagatose Yield and Determine Enzyme Activity}

After enriched in MRS enrichment culture, passage them twice. Then inoculate strains into fermentation medium. After training for $24 \mathrm{~h}$, freeze centrifugate the fermentation broth and abandon the supernate. The precipitation will be washed until it is clean. Finally the precipitation is scattered into potassium phosphate buffer. Then ultrasonic broke it and frozen centrifugal it again. The supernatant is the crude enzyme and it will be got after removing the debris.

Take crude enzyme into vitro and add the substrate which containing D-galactose and $\mathrm{MnCl}_{2}$ and make the potassium phosphate buffer which $\mathrm{pH}$ is 7.0 as the contrast instead of crude enzyme. After reacting in $60^{\circ} \mathrm{C}$ water bath for 1 hour, add $0.5 \mathrm{ml}$ of hydrochloric acid to terminate the reaction. Then according to the modified cysteine carbazole method, compound D-tagatose standard solution and draw the D-tagatose standard curve synchronously [23] [24]. Then measuring the absorbance values under $540 \mathrm{~nm}$ and calculate the conversion rate of D-tagatose. The conversion rate is the specific value of the production yield of D-tagatose in the overall reaction system and the amount of galactose which added in the reaction system reacted after a period time.

\subsubsection{Identify Lactobacillus with High D-Tagatose Yield}

Identify strains through the modified CTAB method to extract genome. Use universal primers of $16 \mathrm{~s}$ rDNA in bacterial to amplify 16 s rDNA. We use primers R1522 and F27 to amplify 16 s rDNA with genome as the template. The PCR reaction annealing at $52^{\circ} \mathrm{C}$ for 1 minute, extended for 50 seconds for a total of 30 cycles and extended for 10 minutes at last. PCR products are detected by agarose gel electrophoresis. The result will be blasted in NCBI, and we select sequences with higher homology to construct the evolutionary tree.

\subsubsection{PCR Amplification of L-Arabinose Isomerase Gene and Clone TA Genes of Lactobacillus with High D-Tagatose Yield}

We search for the related L-arabinose isomerase sequences in GenBank. Analyze the conservatism of L-AI gene by vector NTI 11 software and design the PCR primers. We use primers L-AIR and L-AIF to amplify L-arabinose isomerase gene with genome as the template. The PCR reaction annealing at $59^{\circ} \mathrm{C}$ for 30 seconds, extended for 90 seconds with a total of 30 cycles and extended for 10 minutes at last. The PCR products are detected by agarose gel electrophoresis, and PCR products will be recovered and sent it to Shanghai Sangon for texting.

L-arabinose isomerase gene (L-AI) will be colon into T3 vector and colonies which corresponding to purpose gene will be cultured in LB liquid medium. Then the recombinant plasmid will be sent to Shanghai Sangon sequencing to determine whether it is the positive cloning.

\subsubsection{Bioinformatics Research of L-AI Genes of Lactobacillus with High D-Tagatose Yield}

Reference to the related bioinformatics method in literatures, we get L-AI gene with high D-tagatose yield of L-lactic acid bacteria by comparing to the L-AI gene in L-lactic acid bacteria which using the National Center for Biotechnology Information (National Center for Biotechnology Information, NCBI) [25] [26]. And combine with other bioinformatics analysis softwares, such as the Vector NTI, SWISSMODEL and other tools online (Table 1) to predict protein secondary and tertiary structures of the encoding gene. Then analyze the transmembrane helical, signal peptide, hydrophobicity and the across membrane structure.

\subsubsection{Research of Enzymology Properties of Lactobacillus with High D-Tagatose Yield}

L. plantarum WU14 was activated by MRS culture medium, we suspend strains and the thick enzyme fluid is dispersed in potassium phosphate buffer which $\mathrm{pH}$ is 7.0 with the proportion of $1 / 10$ of the original cultures and will be broken by ultrasonic. The engineering strains and thick enzyme fluid will react respectively for 1 hour at $20^{\circ} \mathrm{C}$ and $30^{\circ} \mathrm{C}, 40^{\circ} \mathrm{C}, 45^{\circ} \mathrm{C}, 50^{\circ} \mathrm{C}$ and $55^{\circ} \mathrm{C}, 60^{\circ} \mathrm{C}, 65^{\circ} \mathrm{C}$ and $70^{\circ} \mathrm{C}$ with potassium phosphate buffer as solvent, and D-galactose which including $\mathrm{MnCl}_{2}$ as substrate. Then use cysteine carbazole method to determine the optimum reaction temperature of enzymatic activity. 


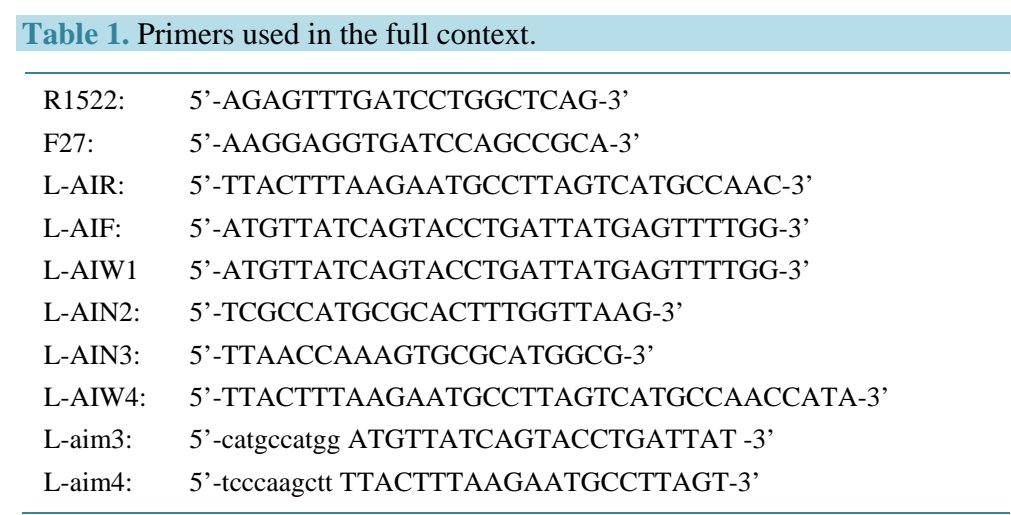

On the basis of the best reaction temperature and the substrates, the $0.83 \mathrm{~mol} / \mathrm{L} \mathrm{D}$-galactose including $\mathrm{MnCl}_{2}$, we put the engineering strain and strain thick enzyme fluid under the conditions acetic acid sodium acetate buffer which $\mathrm{pH}$ is 4.21 , phosphate buffer which $\mathrm{pH}$ is 5.60, 6.24, 7.17 and 5.60, sodium carbonate, and sodium bicarbonate buffer which $\mathrm{pH}$ is 9.11 to determine the optimum $\mathrm{pH}$ of the reaction.

Based on the optimum reaction temperature and the optimum $\mathrm{pH}$, put the engineering strains and strain thick enzyme fluid in different levels of D-galactose substrate containing $\mathrm{MnCl}_{2}$ which concentration are $0.40 \mathrm{~mol} / \mathrm{L}$, $0.60 \mathrm{~mol} / \mathrm{L}, 0.80 \mathrm{~mol} / \mathrm{L}, 1.00 \mathrm{~mol} / \mathrm{L}$ and $1.20 \mathrm{~mol} / \mathrm{L}$ respectively, to measure the conversion rate in order to screen the most suitable substrate concentration after reacting for 28 hours.

We put the engineering strains and thick enzyme fluid reacting for 1 hour under $\mathrm{Mn}^{2+}, \mathrm{Zn}^{2+}, \mathrm{Cu}^{2+}, \mathrm{Mg}^{2+}$, EDTA which the final concentrations is $10 \mathrm{mmol} / \mathrm{L}$, and with the best reaction temperature, $\mathrm{pH}$, and substrate concentration and with the stoste as comparison to determine the enzyme activity.

\subsubsection{Construct L. lactis NZ9000/pRNA48-L-AI}

The pRNA48 plasmid of L. lactis NZ9000/pRNA48 strains is extracted by high pure Plasmid Kit and purified by gel extraction after removing of NcoI enzyme gene loci through recombinant PCR technology by primers L-AIW1, L-AIN2, L-AIW3and L-AIN4. The recombinant L-AI gene can be added Nco I and Hind III enzyme gene loci simultaneously by primers L-aim3 and L-aim4. After purificating, we use CIAP to dephosphorylate the linear pRNA48 plasmid, and then connecting linear pRNA48 with L-AI gene at $14^{\circ} \mathrm{C}$ for 22 hours. Then inactivating it at $65^{\circ} \mathrm{C}$ for 15 minutes. And the connection product will be recovered and purified. Connected product will be shocked into L. lactis NZ9000 cells through the electroporation process. Choose the transformation clones on Mel-EL1 tablet with a yellow halo under purple background $\left(\mathrm{Mel}^{+}\right)$and cultured them in GEL1 all the night.

\subsubsection{Determine the Best Induced Dose of L-AI Gene}

The positive clones, L. lactis NZ9000/pRNA48-L-AI strains will be activated by GEL1 medium and inoculated into GM17 medium to culture at $30^{\circ} \mathrm{C}$ all the night. Then inoculate into GM17 medium at $30^{\circ} \mathrm{C}$ for 3 to 4 hours until the OD value reaches 0.45 to 0.50 [27]. Add soluted nisin with the final concentration is about $10 \mathrm{ng} / \mathrm{mL}$ to $40 \mathrm{ng} / \mathrm{mL}$ into bacteria culture and induce them at $30^{\circ} \mathrm{C}$ for 12 hours. Extract the total bacterial protein of the bacteria under different concentrations and analyze them by SDS-PAGE. Then measure the enzyme activity in order to select the best induction dose. In addition, according to the best induction dose, it will be inducted training for 0 h, 4 h, 8 h, 12 h, 16 h, respectively. Then extracting the total protein in different induction time, and analyzing it by SDS-PAGE and measure enzyme activity of the crude enzyme through the modified cysteine carbazole method in order to select the best induction time.

\subsubsection{Research the Property of L-Arabinose Isomerase of L. lactis NZ9000/pRNA48-L-AI}

At first, active recombinant bacteria L. lactis NZ9000/pRNA48-L-AI is inoculated into two GM17 mediums and culture for 4 hours. Then adding nisin until the final concentrantion is $30 \mathrm{ng} / \mathrm{mL}$. After training for 12 hours, the recombinant strains and thick enzyme fluid broken by ultrasonic for 12 minutes will be suspended with potassium phosphate buffer ( $\mathrm{pH} 7.0$ ) with 1/10 of the original cultures of volume.

The recombinant strains and thick enzyme fluid react under the condition of $20^{\circ} \mathrm{C}, 30^{\circ} \mathrm{C}, 40^{\circ} \mathrm{C}, 45^{\circ} \mathrm{C}, 50^{\circ} \mathrm{C}$ 
and $55^{\circ} \mathrm{C}, 60^{\circ} \mathrm{C}, 65^{\circ} \mathrm{C}$ and $70^{\circ} \mathrm{C}$ respectively for 1 hour, and then determine enzyme activity with $0.2 \mathrm{~mol} / \mathrm{L}$ potassium phosphate buffer ( $\mathrm{pH} 7.0$ ) and $0.83 \mathrm{~mol} / \mathrm{L}$ of $\mathrm{D}$-galactose (including $\mathrm{MnCl}_{2}$ ) as solvent and substrate respectively.

Based on the best reaction temperature and the $0.83 \mathrm{~mol} / \mathrm{L}$ of D-galactose substrates with $\mathrm{MnCl}_{2}$, the recombinant bacteria strains and strain thick enzyme fluid react under the condition of acetic acid sodium acetate buffer ( $\mathrm{pH} 4.21$ ), phosphate buffer ( $\mathrm{pH} 5.60,6.24,7.17,8.04)$ and sodium carbonate, sodium bicarbonate buffer (pH 9.11) to determine the enzyme activity.

Based on the optimum reaction temperature and the optimum $\mathrm{pH}$, the recombinant bacteria strains and thick enzyme fluid react under the condition of $0.40 \mathrm{~mol} / \mathrm{L}, 0.60 \mathrm{~mol} / \mathrm{L}, 0.80 \mathrm{~mol} / \mathrm{L}, 1.00 \mathrm{~mol} / \mathrm{L}$ and $1.20 \mathrm{~mol} / \mathrm{L}$ of D galactose substrates with $10 \mathrm{mmol} / \mathrm{L} \mathrm{MnCl}_{2}$ respectively for 28 hours and measure the conversion rate in order to screen the best substrate concentration of the transfer reaction.

According to the best reaction temperature, $\mathrm{pH}$, and substrate concentration with the comparison of stoste, they will react for 1 hour to determine enzyme activity in order to understand the influence of the transformation of different ions on enzyme reaction under the condition of the final concentration is $10 \mathrm{mmol} / \mathrm{L}$ of $\mathrm{Mn}^{2+}, \mathrm{Zn}^{2+}$, $\mathrm{Cu}^{2+}, \mathrm{Mg}^{2+}$ and EDTA.

\section{Results and Discussion}

\subsection{Activate Lactobacillus with High D-Tagatose Yield and Determine Enzyme Activity}

According to thin layer chromatography (TLC), we screen out 64 strains which have the bioconversion ability of transforming D-galactose to D-tagatose from more than 800 lactic acid bacteria in pickles and pickled vegetables with D-tagatose standard product as contrast. And because of the result of 10 strains with deeper color, we extract the coarse enzyme and re-screen strains through the modified cysteine carbazole method [23] [24]. Then measure the OD value at $540 \mathrm{~nm}$, and draw D-tagatose standard curve. Calculate the enzyme activity of the corresponding strains' crude enzyme and enzyme activity can reach to $13.95 \mathrm{U} / \mathrm{mL}$ (Figure 1).

\subsection{Identify Lactobacillus with High D-Tagatose Yield}

Identify the strain WU14 with high D-tagatose yield through gram staining and biochemical method. According to the result, the characteristic of gram-positive coincides with the speciality of lactobacillus [28]. And the result is negative according to catalase test and hydrogen sulfide test. Then complete genome of WU14 was texted by agarose gel electrophoresis which had less fracture. So it is beneficial to amplify special positions. Using the

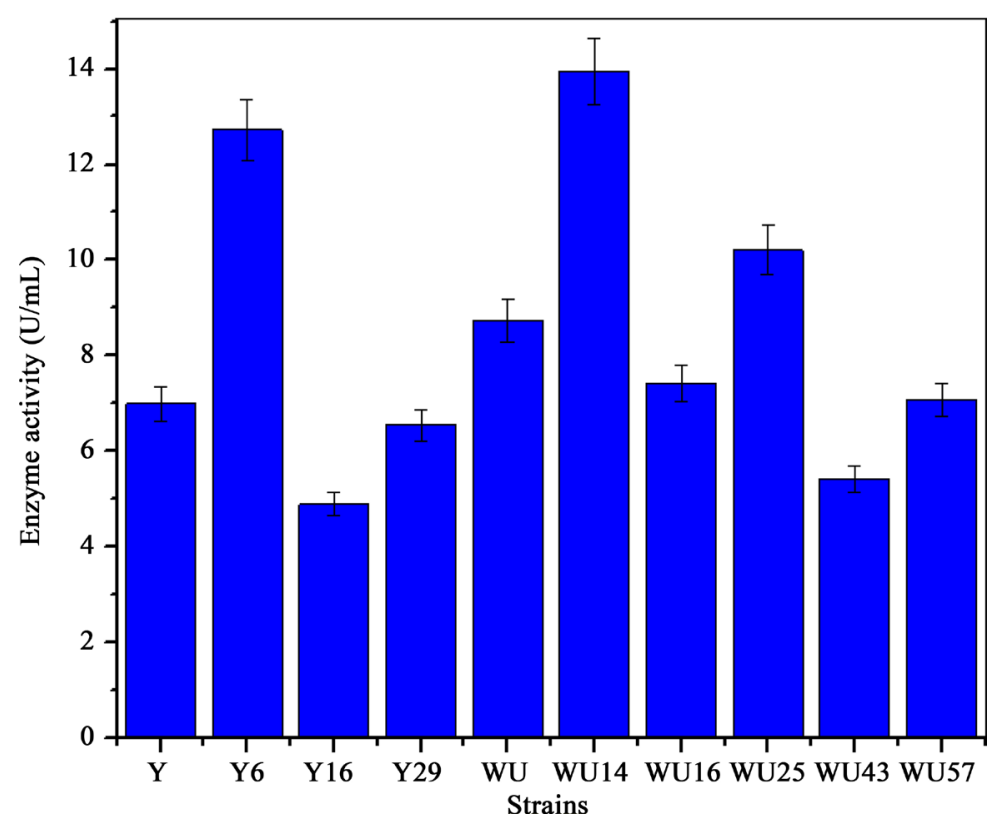

Figure 1. The determination of enzyme activity of 10 strains of high yield D-tagatose. 
complete genome to amplify 16 s rDNA gene, and then obtaining two 1450 bp bands of the two duplicate samples. Then the BLAST software was used to align the sequences of the strain. And the evolutionary tree was constructed by ClustalW2 and Treeview software. The results from the NCBI database data showed that the similarity between the $16 \mathrm{~s}$ rDNA sequence of WU14 strains and L. plantarum MJ0301 reached 99\% (Figure 2) and it indicated that the strain is Lactobacillua plantarum.

\subsection{Amplify and Analyze L-AI Gene}

Amplify L-AI gene of Lactobacillua plantarum WU14 with the whole genome as a template, and we obtain two bands which are about 1425bp, its size is similar to L-Arab sugar isomerase gene of L. plantarum ST-III, L. plantarum WCFS1 and L. plantarum JDM1. The similarity between sequences of L-AI in Lactobacillua plantarum reached 99.5\% through aligning the results in BLAST.

Based on the alignment sequence, we found that the 907th bases pair was C in L-AI gene of WU14 strains, and it was different from $\mathrm{T}$ in all bases pairs in NCBI database. CTT encode leucine but TTT encode phenylalanine. Moreover the 1108th base pair T in L-AI gene of WU14 is different from A in the site of this place in all L-AI gene of plantarum lactobacillus, the former codes GCC coding alanine but the ACC codes threonine. These differences will lead to the difference of the translation of L-AI. Whether these different base pairs will cause the changes of biochemistry of the enzyme, and it will be researched further in the future. L-AI of the two Lactobacillua plantarum strains will be connected with pGEM-T carrier, and hot shot into E. coli DH5 $\alpha$ cells.

Analyze L-AI gene of Lactobacillua plantarum WU14 through biological analysis software Vector NTI. The gene has common restriction enzymes such as Nco I, BstE II, Apa I, Afl III, Bgl II, Hae III and Nde I, which can be used as enzyme sites to construct L-AI gene expression vector in the next step and make point mutation (Figure 3). In addition, plus strands of L-AI have open reading frame 1 and the reading frame have the starting codon ATG and the termination codon TAA. It can encode from the first base to the 1422th bases in total of 474 codes, and it encode 474 amino acids that contract the primary protein structure of L-AI.

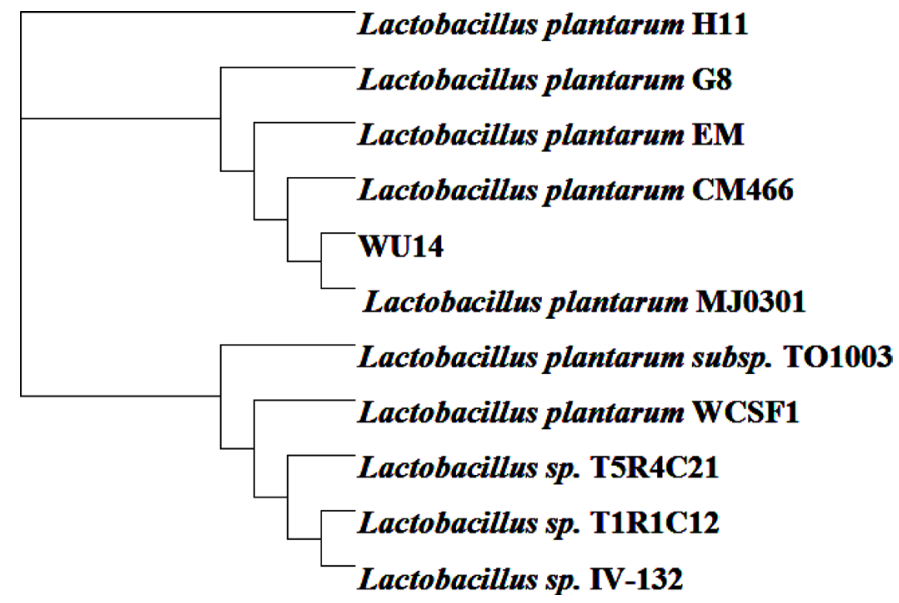

Figure 2. The phylogenetic tree of WU14.

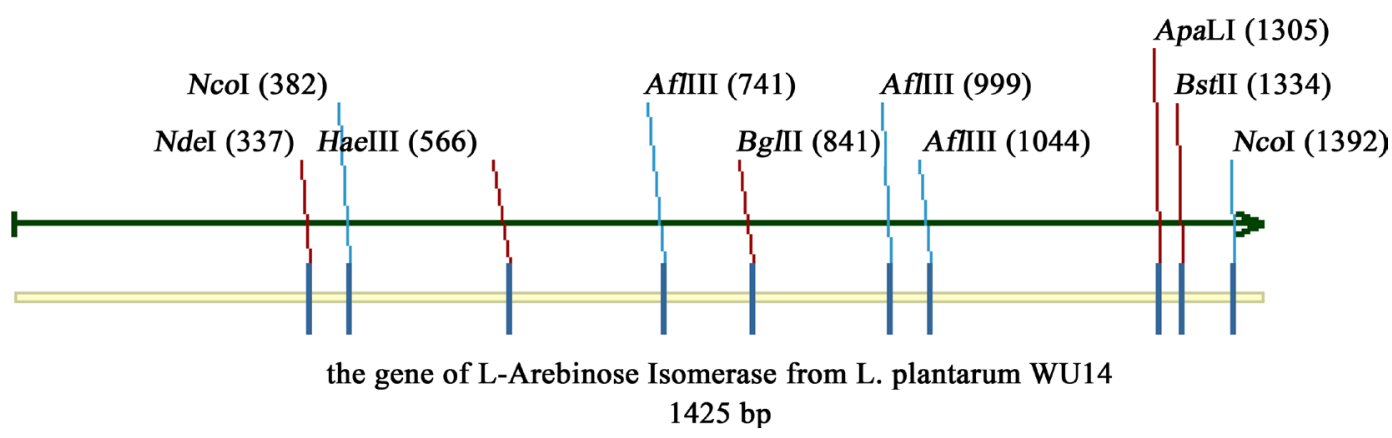

Figure 3. The gene sequence of L-AI of L. plantarum WU14 and restriction enzyme sites. 


\subsection{Bioinformatics Research of L-AI Genes of Lactobacillus with High D-Tagatose Yield}

Through the SOPM prediction method of protein secondary structure in NPS network website to analyze the secondary protein structure encoded by L-AI gene of $L$. plantarumWU14. The results indicate that there are 227 amino acid residues can form Alpha the helix and random coil is composed of 121 amino acid residues which are accounted for $47.89 \%$ and $25.53 \%$ of the total secondary structure respectively (Figure 4 ). In other words that the alpha helix and random coil consisted of the subject of secondary protein structure of L-AI and the result can be found in other microorganisms, such as Escherichia coli [6]. And L-AI also has some conserved amino residues which exist in various microorganisms [29]. The analysis results of transmembrane protein helical of L-AI protein have been texted by TMHMM online analysis software. The L-AI protein of L. plantarum WU14 have no transmembrane protein structure. And protein hydrophobicity map calculated by ProtScale program of ExPASy showed the L - AI protein is hydrophilic protein.

\subsection{Research of Enzymology Properties of L. plantarum WU14 with High D-Tagatose Yield}

Temperature has obvious influence on enzyme activity and it is closely linked to catalytic velocity of enzymatic reaction. And when it rises to a certain point, the rate of enzymatic reaction will reach the maximum value. As Figure 5 shown that the optimal temperature was $60^{\circ} \mathrm{C}$ for L-Arab sugar isomerase in L. plantarum WU14 which is higher than other Lactobacillus plantarum $\left(50^{\circ} \mathrm{C}\right)$ but it is similar to Lactobacillus SK $1.002\left(60^{\circ} \mathrm{C}\right)$ [24] [30]. In addition, the heat resistance of enzyme is relatively good when the temperature rise to $65^{\circ} \mathrm{C}$, and the enzyme activity is wrecked less than $30 \%$ compared with the optimal enzyme activity. Meanwhile the enzyme activity of crude enzyme is significantly higher than that from the bacteria suspension under the optimal temperature in a certain enzymatic reaction time and it maybe because of catalytic center of crude enzyme broken fully has more contact area with substrate. The Lactobacillus plantarum with high optimum temperature can solve the difficulties of mechanical heating and cooling in industrial fermentation process and predispose reaction balance point to the production of D-tagatose in order to cost reduction and raise production [32].

The optimum $\mathrm{pH}$ of L-Arab sugar isomerase of L. plantarum WU14 is 7.17, moreover this enzyme has strong acid-resistant ability relative to the L-arabinose isomerase of other strains [24]. When pH is 6.24 and 5.60 , its enzyme activity will reduce only $11 \%$ and $34 \%$ compared to the enzyme activity in the optimum pH and still has $28.43 \%$ of the enzyme activity in $\mathrm{pH} 4.21$ (Figure 6). And this is different from L-arabinose isomerase in other species obviously such as Pdeiocccus pentosaceu and Thermotoga neapolitana [32]. The reason of the acid-resistant ability of L-arabinose isomerase of $L$. plantarum WU14 may because of the strains were selected from the lactic acid bacteria in pickles with strong acidic taste and there are a certain proportion of acidic amino acids in the protein of L-AI gene in L. plantarum WU14 [33]. Some undesirable effects of the industrial production

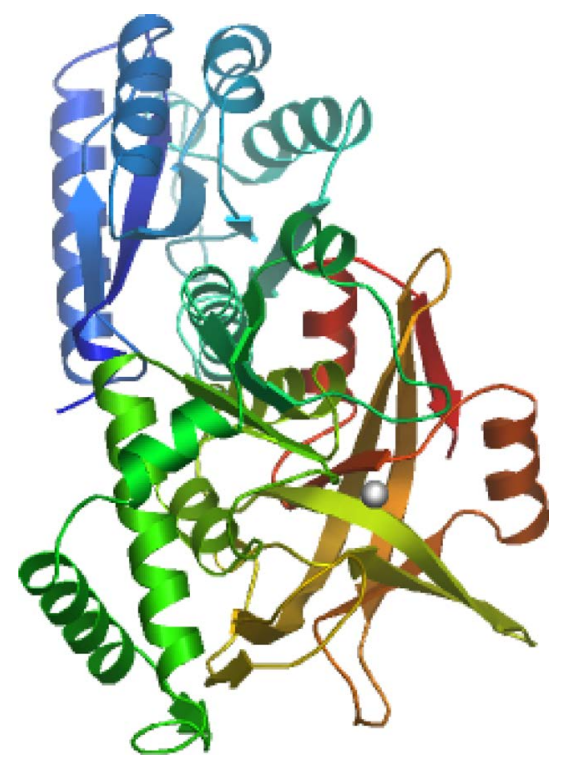

Figure 4. Three dimensional structures prediction of L-AI of L. plantarum WU14. 


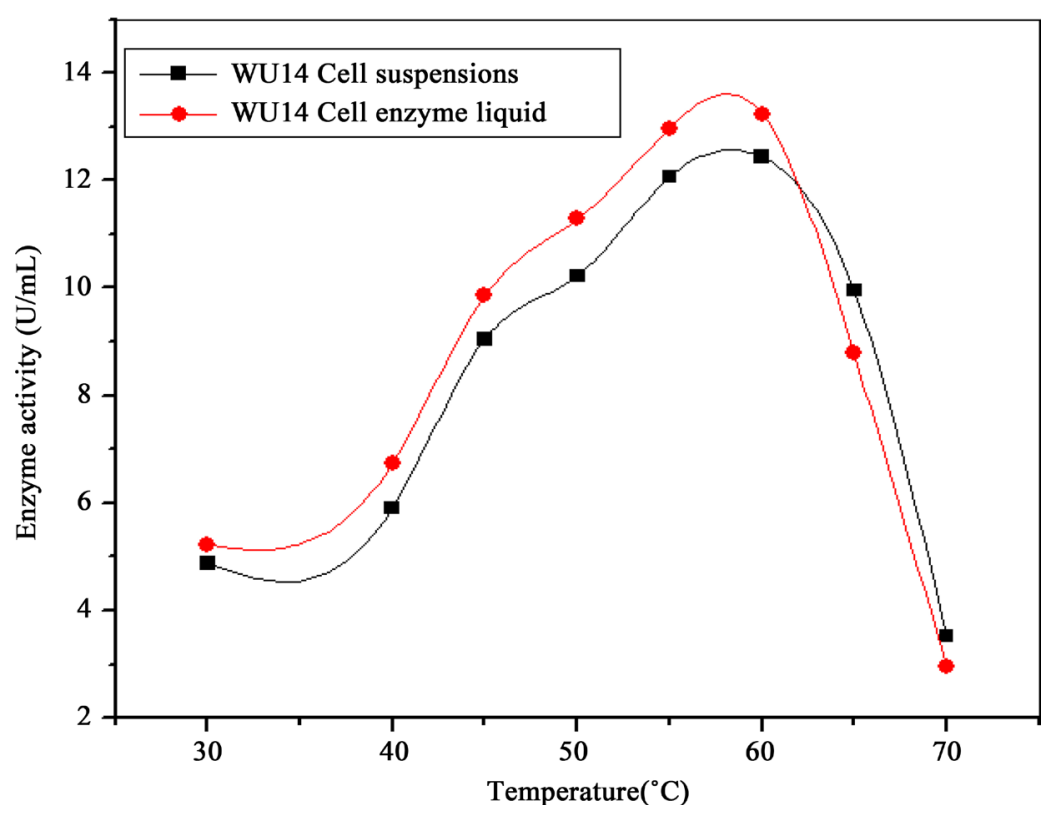

Figure 5. The optimal temperature curve of the conversion reaction of L-AI of L. plantarum WU14. The circles icons represent the crude enzyme which was broken by ultrasonic. And the square icons represent the enzyme in bacteria suspension.

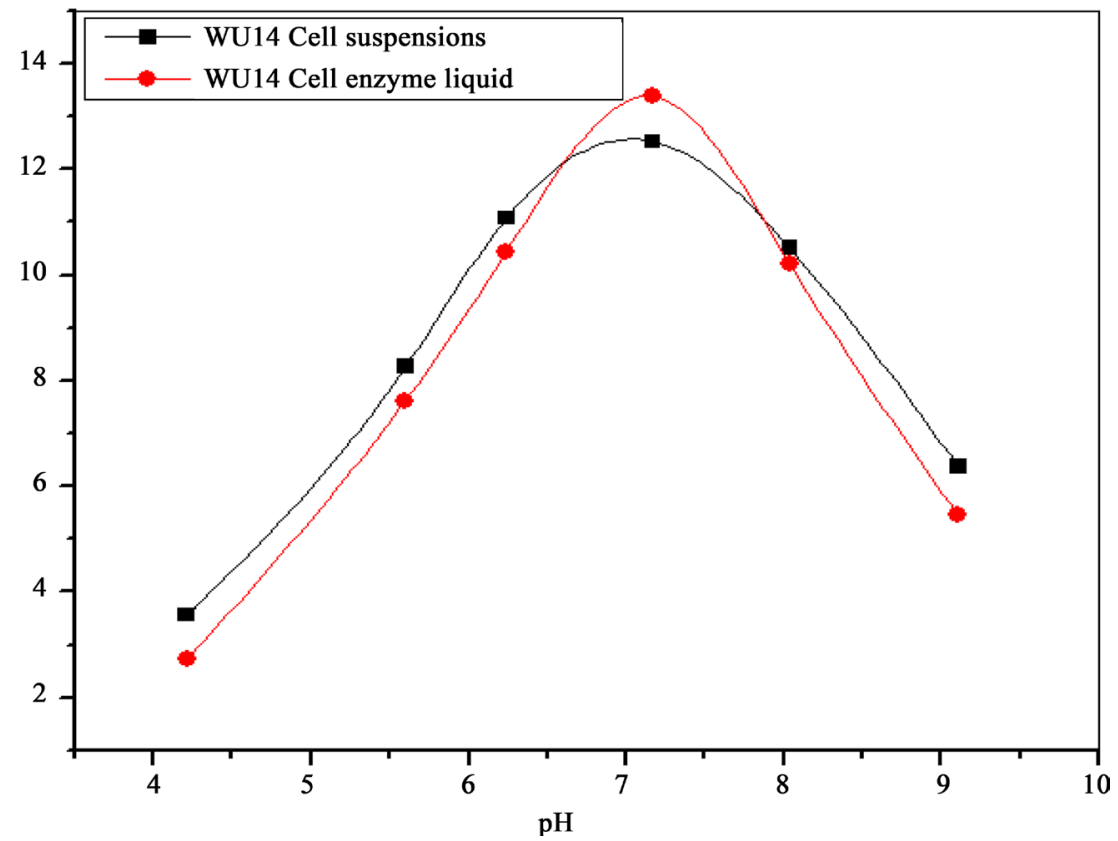

Figure 6. The optimal pH curve of the conversion reaction of L-AI of L. plantarum WU14. The circles icons represent the crude enzyme which was broken by ultrasonic. And the square icons represent the enzyme in bacteria suspension.

and other miscellaneous bacterium contaminations can be greatly reduced by the acid-resistant ability through adjusting the $\mathrm{pH}$ of $\mathrm{L}$-arabinose isomerase in L. plantarum WU14 [38].

As Figure 7 and Figure 8 shown to us, the transformation rates of the bacteria suspending fluid and the thick enzyme reached the highest point under the condition of the substrate concentration is $0.8 \mathrm{~mol} / \mathrm{L}$ after 28 hours. And the rate of bacteria suspending fluid reached $56.12 \%$ which can be illustrated that the optimum substrate concentration of transforming L-arabinose isomerase was $0.8 \mathrm{~mol} / \mathrm{L}$. Meanwhile the transformation rate of crude enzyme is slightly higher than bacteria suspending fluid in the first 4 hours. It indicated that the stability of the crude enzyme is worse than enzyme in suspending fluid. And the transformation rate of L-AI in L. plantarum 
WU14 are comparable with other lactobacillus and thermophilic microorganism and such as L. plantarum (60\%) Lactobacillus reuteri (35\%) and T. maritime ( $\geq 56 \%)$ [30] [34]. In addition, the stability of thermal and $\mathrm{pH}$ of bacteria is better than crude enzyme this maybe because of the influence with cell breakage, the protection of intracellular membranes, the prosthetic group and the coenzyme [35] (Figure 7 and Figure 8).

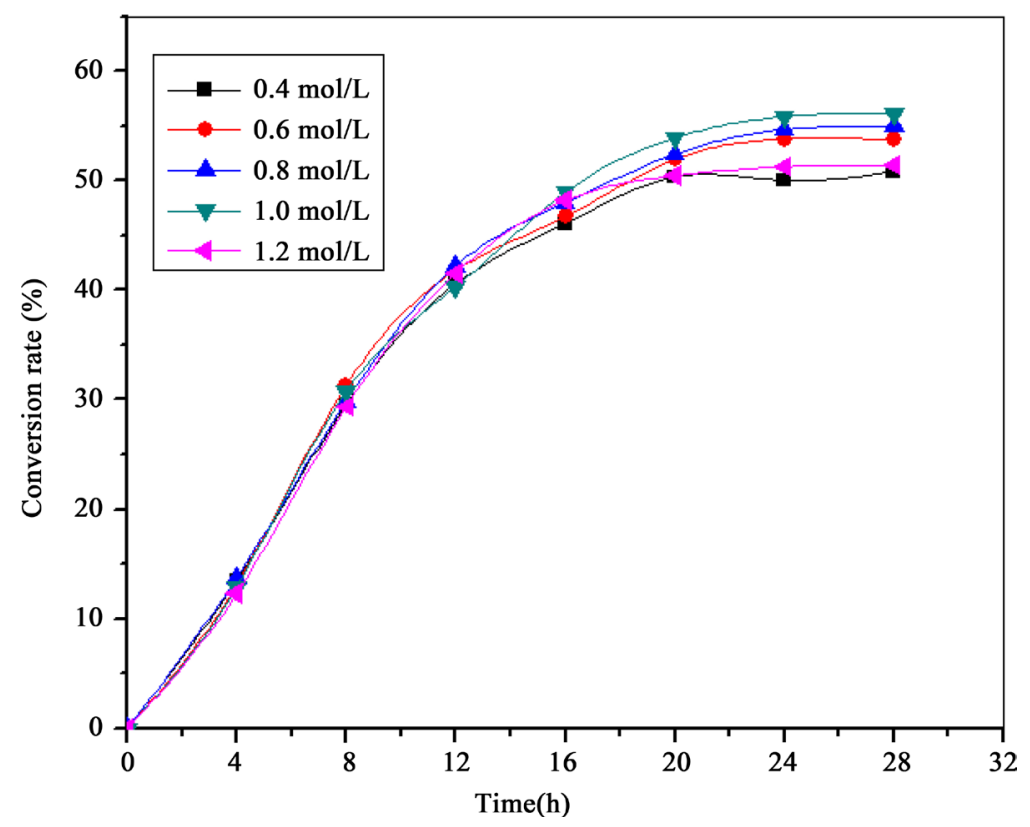

Figure 7. The effect of substrate concentration on conversion reaction of suspended bactreia liquid of $L$. plantarum WU14.The square icons, circles icons, the triangle icons, the inverted square icons and the triangle icons on side represent the substrate concentration which is $0.4 \mathrm{~mol} / \mathrm{L}, 0.6 \mathrm{~mol} / \mathrm{L}, 0.8 \mathrm{~mol} / \mathrm{L}, 1.0 \mathrm{~mol} / \mathrm{L}$ and $1.2 \mathrm{~mol} / \mathrm{L}$ in medium of suspended bactreia liquid respectively.

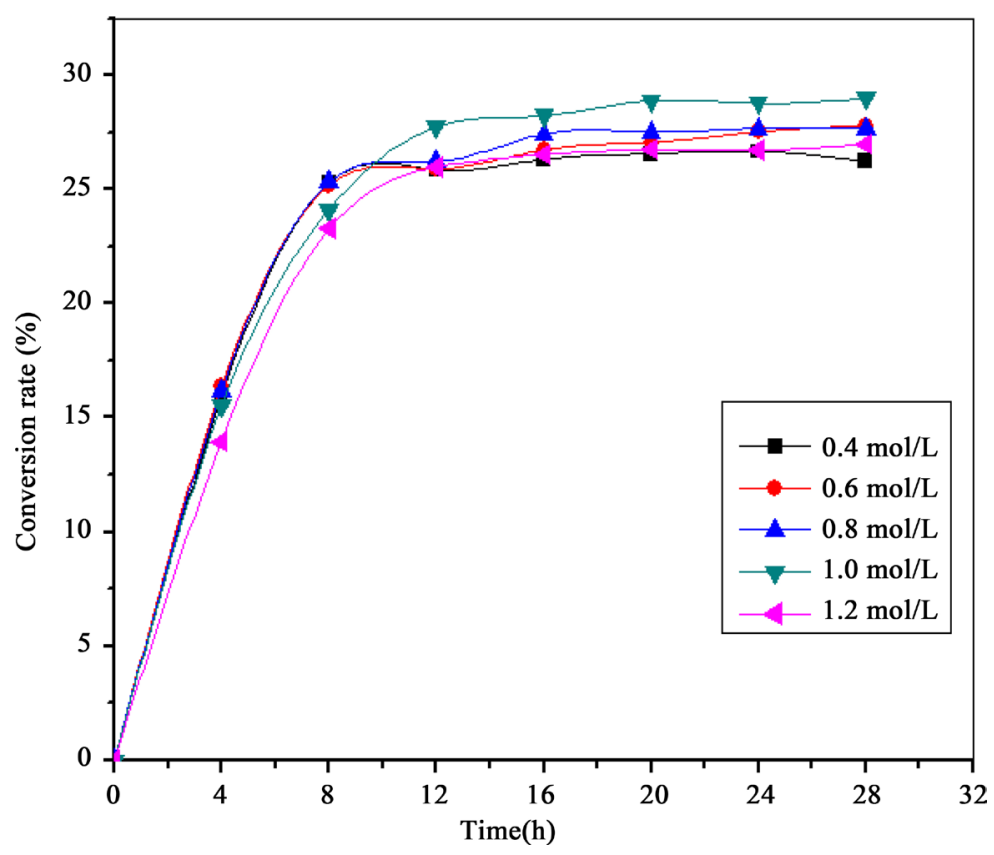

Figure 8. The effect of substrate concentration on conversion reaction of crushing coarse enzyme liquid of $L$. plantarum WU14. The square icons, circles icons, the triangle icons, the inverted square icons and the triangle icons on side represent the substrate concentration which is $0.4 \mathrm{~mol} / \mathrm{L}, 0.6 \mathrm{~mol} / \mathrm{L}, 0.8 \mathrm{~mol} / \mathrm{L}, 1.0 \mathrm{~mol} / \mathrm{L}$ and $1.2 \mathrm{~mol} / \mathrm{L}$ in medium of crushing coarse enzyme liquid respectively. 
The metal ions $\mathrm{Mn}^{2+}$ and $\mathrm{Mg}^{2+}$ have some promoting effects on conversion reaction. And the reaction rate reached three times more than the original enzyme before when $\mathrm{Mn}^{2+}$ were added. The $\mathrm{Mn}^{2+}$ is the prosthetic group in active center. The results can be seen in various researches, such as in Pediococcus pentosaceus PC-5 and Escherichia coli K-12 [36] [37]. Through the result of comparing the enzyme activity of original bacterium solution with the broken enzyme of the original bacterium solution which added EDTA, we can know the original bacterium solution is seem to have weaker tolerance of high temperature and $\mathrm{pH}$ without little $\mathrm{Mn}^{2+}$. And the L-AI enzyme activity is obvious lower than the ordinary ones (Figure 9). In addition, $\mathrm{Cu}^{2+}$ and $\mathrm{Zn}^{2+}$ has strong inhibitory effects to L-AI which is similar to the L-AI in Escherichia coli $\mathrm{K}-12$, and the enzyme activity is only about $2 \%$ to $4 \%$ compared with the ordinary ones [38].

\subsection{Constructing L. lactis NZ9000/pRNA48-L-AI}

The purified ligation mixture was used to transform L. lactis NZ9000 competent cells by electroporation. The cells were incubated for recuperation in SM17MC medium. After recuperation, electroporated cells were inoculated into Mel-EL1 medium and incubated at room temperature until acidification, and it was manifested by a color change (from purple to yellow) of the $\mathrm{pH}$ indicator purple bromocresol as shown in the Figure 10.

Then, cells were diluted in sterile peptonized water, plated on Mel-BCP plates. Plasmid DNA was recovered from the $\mathrm{Mel}^{+}$(yellow) colonies and digested with Nco I and Hind III. Then the two bands of 4500 bp and

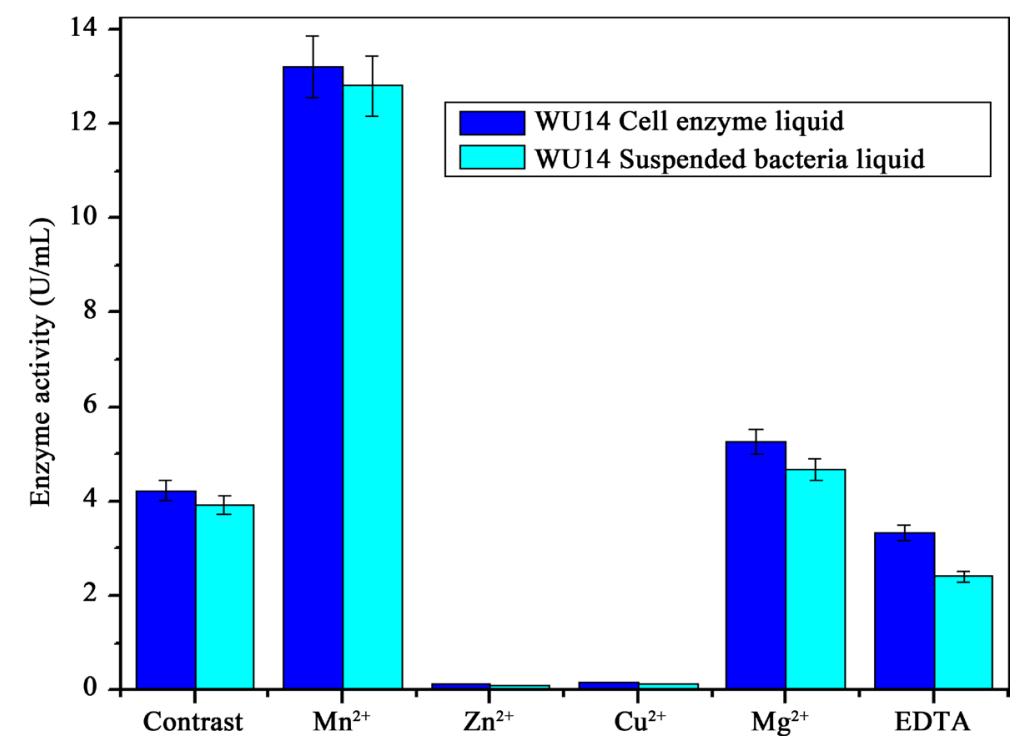

Figure 9. Effects of various metallic ions and EDTA on L-AI WU14 activity. The azury bars represent suspended bactreia liquid and the dark blue bars represent crushing coarse enzyme liquid.

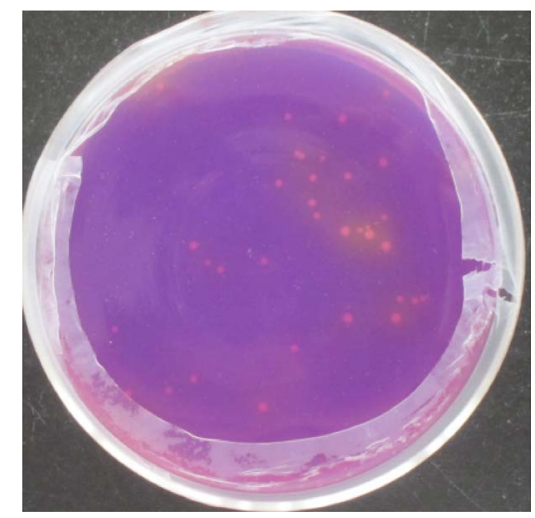

Figure 10. The filtered results of recombinants on the Mel-BCP plate. The yellow colonies on the plate indicate that $L$. lactis NZ9000/pRNA48-L-AI was constructed successfully. 
1500 bp we got were in accord with the theoretical results. At the same time, the recombinant plasmid was amplified by PCR with the L-aim3 and L-aim4 primers, as shown in Figure 11, the sizes of the fragment was same to the original L-AI gene, and the sequence of the PCR product was $99.9 \%$ similarity to the original -AI gene after detection. Therefore, the food-grade expression vector pRNA48-L-AI was constructed successfully.

\subsection{Using SDS-PAGE Technology to Choose the Best Induction Dose and Time of Expressing L-AI Gene Induced by Nisin}

After inducing for 12 hours, we extract the protein of recombinant strains L. lactis NZ9000/pRNA48-L-AI from different concentration of nisin. As the shown in Figure 12, L-arabinose isomerase have been expressed in $L$. lactis NZ9000 successfully and molecular weight of L-AI is $52.6 \mathrm{kDa}$ which coincided with the predicted molecular weight. L-AI are various in diverse species, such as E. coli AI (ECAI) the earliest L-AI we known the structure and the molecular weight of the hexamer is $336 \mathrm{kDa}$ [35]. The L-AI of the engineering bacteria has the highest enzyme activity with the induction dose $30 \mathrm{ng} / \mathrm{mL}$, and the protein reached the maximum. But when we continue to add the induction dose until $40 \mathrm{ng} / \mathrm{ml}$, the enzyme activity will be slightly reduced. So the best induced dose of L-AI gene expression is $30 \mathrm{ng} / \mathrm{mL}$ (Figure 13). Then the total protein of the bacterium in different induction time was analyzed by SDS-PAGE method and the crude enzyme activity was measured. As shown in Figure 14 and Figure 15, the L-AI expression reached the largest and enzyme activity attained the maximum at the same time at the optimum induction time 12 hours.

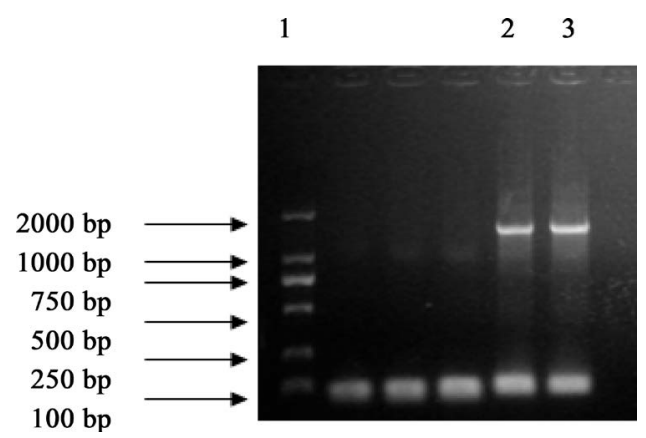

Figure 11. Identification the recombinant plasmid by PCR.Line1 DL2000 DNA Marker; Line 2, 3 PCR product of recombinant plasmid.

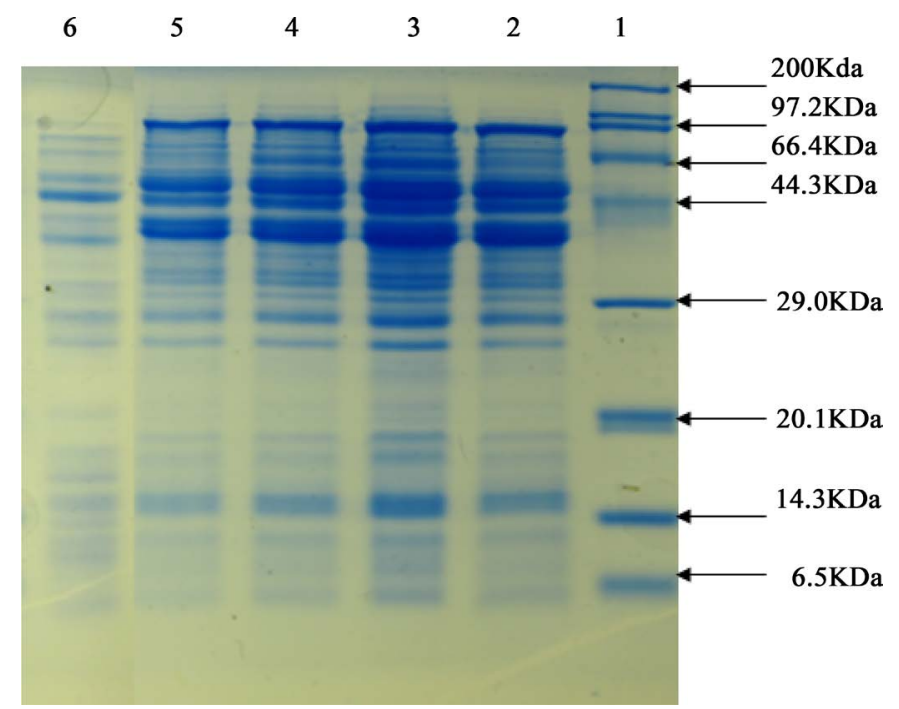

Figure 12. Identification the target protein by SDS-PAGE under the different induced concentration of nisin. Line 1 Protein molecular weight marker (Wide); Line 2 the protein induced by $40 \mathrm{ng} / \mathrm{mL}$ nisin; Line 3 the protein induced by $30 \mathrm{ng} / \mathrm{mL} \mathrm{ni}-$ sin; Line 4 the protein induced by $20 \mathrm{ng} / \mathrm{mL}$ nisin; Line 5 the protein induced by $10 \mathrm{ng} / \mathrm{mL}$ nisin; Line 6 the protein without nisin. 


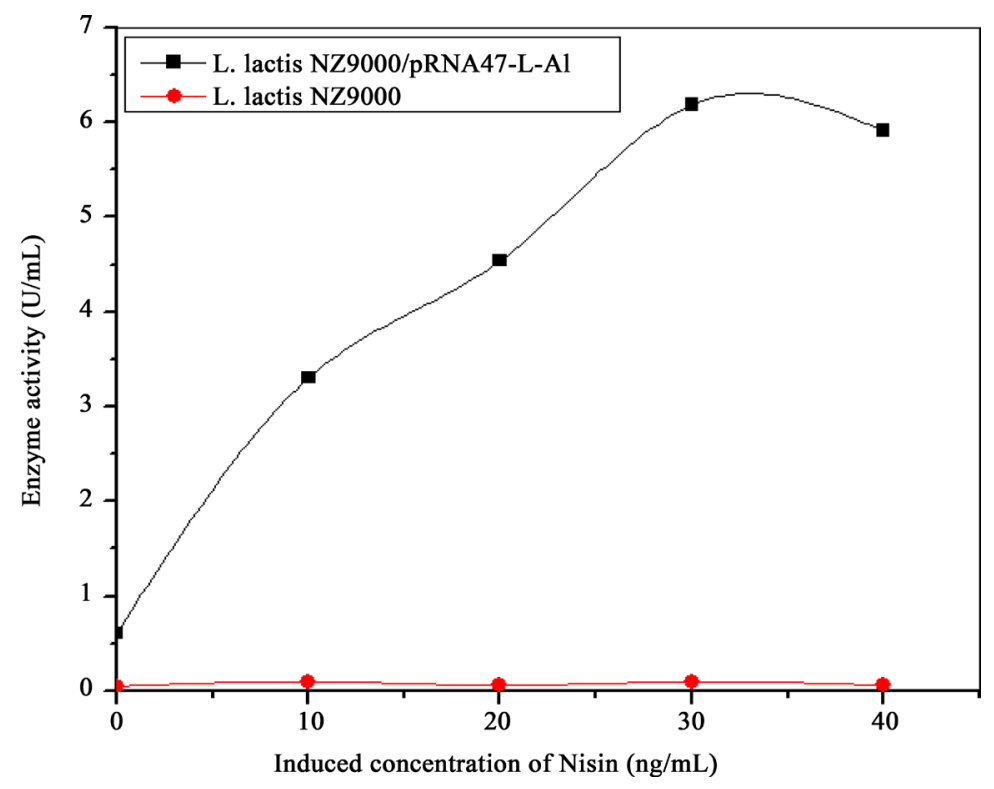

Figure 13. The crude enzyme activity curve of L. lactis NZ9000/pRNA48-L-AI recombinant bacteria and L. lactis NZ9000 under the different induced concentration of nisin. The square icons represent $L$. lactis NZ9000/pRNA48-L-AI recombinant bacteria, and the circles icons represent $L$. lactis NZ9000 bacteria.

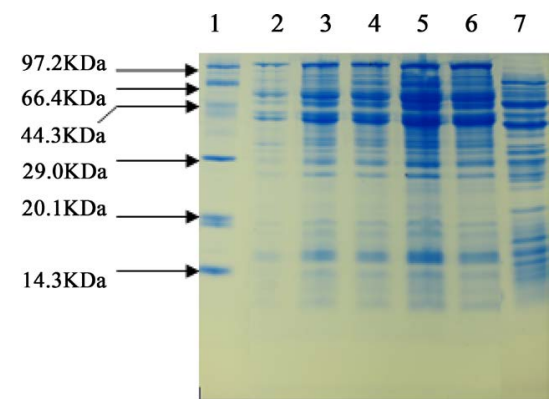

Figure 14. Identification the target protein by SDS-PAGE under the different induced time. Line 1 Protein molecular weight marker (low); Line 2 the protein by 0 h; Line 3 the protein by 4 h; Line 4 the protein by 8 h; Line 5 the protein by 12 h; Line 6 the protein by $16 \mathrm{~h}$; Line 7 the protein without nisin by $48 \mathrm{~h}$.

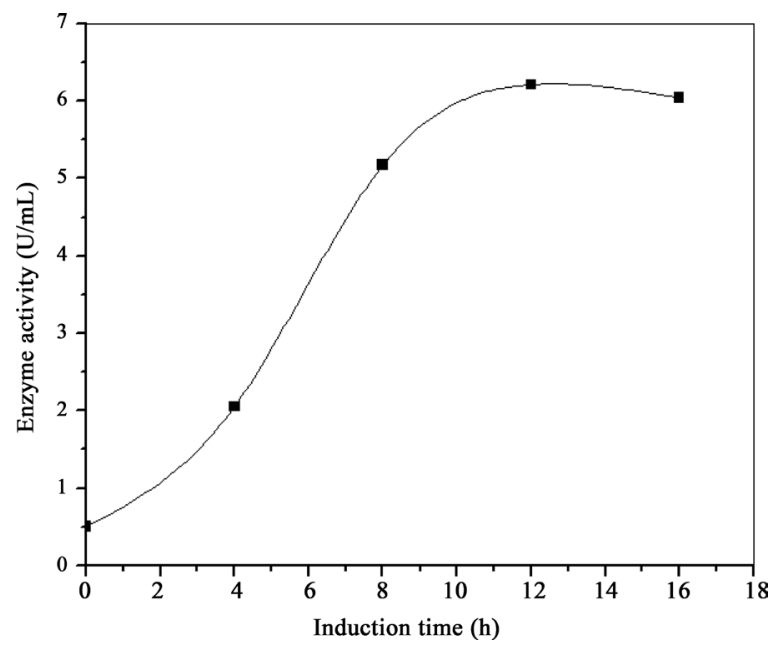

Figure 15. The crude enzyme activity curve of L. lactis NZ9000/pRNA48-L-AI under the different time. The square icons represent $L$. lactis NZ9000/pRNA48-L-AI recombinant bacteria inducted in different time. 


\subsection{The Enzymatic Property Research of L-Arabinose Isomerase of Recombinant Bacteria L. lactis NZ9000/pRNA48-L-AI}

Many factors can affect enzyme activity, such as temperature, $\mathrm{pH}$, substrate concentration and metal ion, etc. As shown in Figure 16, the optimum temperature of the recombinant bacteria L. lactis NZ9000/pRNA48-L-AI is $50^{\circ} \mathrm{C}$ which is common in L-AI of other specises such as Anoxybacillus flavithermus [29]. And the conversion reaction of L-arabinose isomerase is difficult to continue when the reaction temperature is below $20^{\circ} \mathrm{C}$ in this research. When the temperature is between $20^{\circ} \mathrm{C}$ and $50^{\circ} \mathrm{C}$, the reaction rate is accelerated along with the increase of the temperature and the enzyme activity was almost completely lost at $70^{\circ} \mathrm{C}$. The transformation rates of L-AI can be rised when the temperature increment in microorganism [38]. When the temperature is between $50^{\circ} \mathrm{C}$ and $70^{\circ} \mathrm{C}$, the cell walls and the cell membrane can play a part in maintaining the endoenzyme activity. In addition, the enzyme reaction rate of bacteria suspending liquid rises slower than the thick enzyme between $20^{\circ} \mathrm{C}$ and $50^{\circ} \mathrm{C}$. The enzyme in suspending liquid maybe release incompletely, and the area contacted with the substrate is smaller than thick enzyme.

As shown in Figure 17, the enzymatic reaction reached to the maximum at $\mathrm{pH}$ 7.17. In addition, the enzyme activity will maintain well relatively when the $\mathrm{pH}$ fluctuates between 6 and 9, and the enzyme activity in weak acid environment is higher than that in weak alkaline environment which is different from pH 7 - 9 in Escherichia coli K-12 and pH 8.5 in Anoxybacillus flavithermus [29] [37]. At the range of $\mathrm{pH} 4$ to $\mathrm{pH} 7$, the enzymatic activity rise along with the $\mathrm{pH}$ rising and the characteristic can be discover in Lactobacillus SK1.002, but the optimal $\mathrm{pH}$ is 8.0 [39]. The process of galactose isomerization can produce side reaction under alkaline environment, so the $\mathrm{pH} 7.17$ applies to the industrial production [31].

The concentration of $0.6 \mathrm{~mol} / \mathrm{L}$ was considered as the optimum substrate concentrations through the reaction under the condition of the optimum temperature $50^{\circ} \mathrm{C}, \mathrm{pH} 7.17$ and the different substrate concentrations.

Besides that the conversion rate of the crude enzyme is higher than that in suspending liquid after reacting for 4 hours in Figure 18. And the conversion rate of suspending liquid is far beyond the thick enzyme after 8 hours (Figure 19). Meanwhile, it will no longer increase when the conversion rate of thick enzyme reaches $14.54 \%$ after 16 hours, while the rate of suspending liquid will keep rising until $38.31 \%$ at 28 hours. So that the crude enzyme exposed outside can contact with the substrate fully at first, but the support from coenzyme and prosthetic groups can't be received in the following reaction, so the heat resistance of the crude enzyme is depressed. And it accorded with the basic properties of enzymology in L-AI [35].

Determine the enzyme reaction activity of thick enzyme of L. lactis NZ9000/pRNA48-L-AI and enzyme

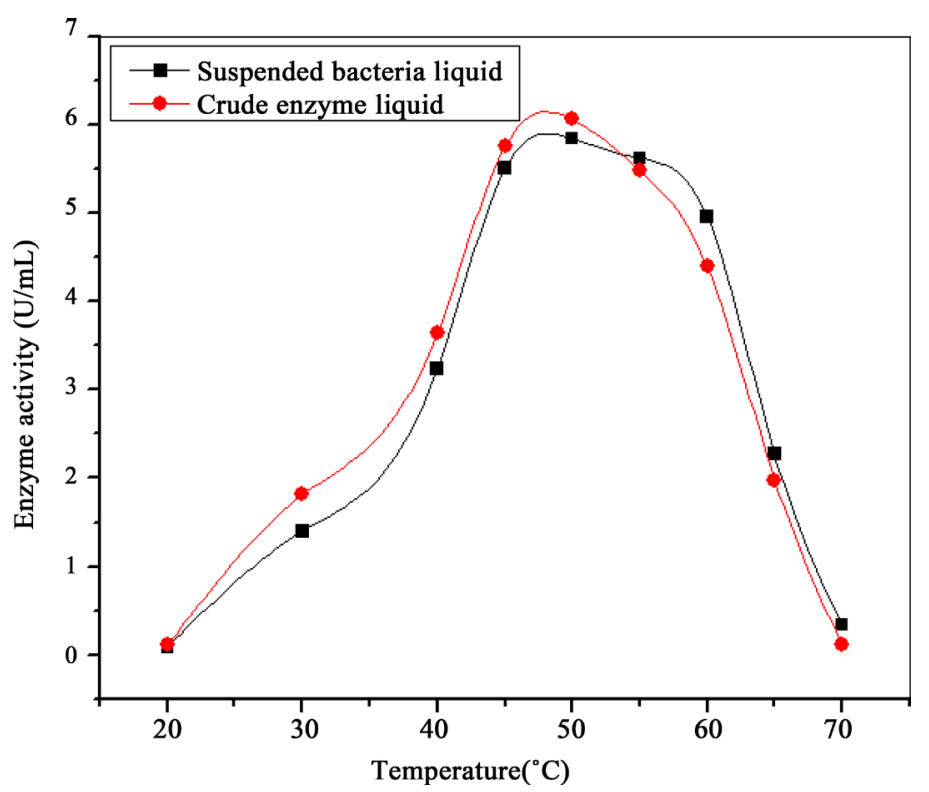

Figure 16. The optimal temperature curve of the conversion reaction of L-AI of L. lactis NZ9000/pRNA48-L-AI. The circles icons represent the crude enzyme which was broken by ultrasonic. And the square icons represent the enzyme in bacteria suspension. 


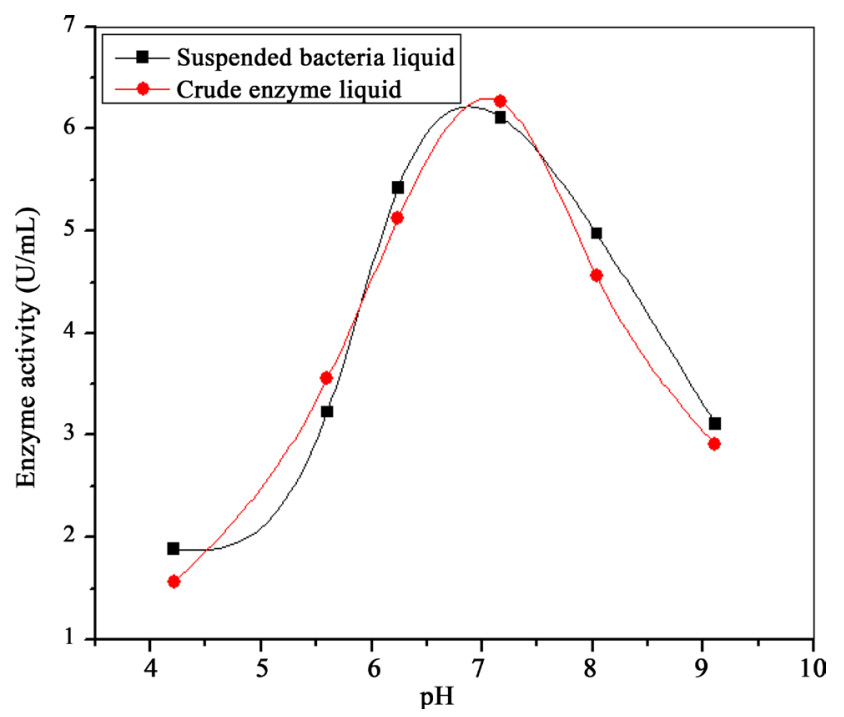

Figure 17. The optimal pH curve of the conversion reaction of L-AI of L. lactis NZ9000/pRNA48-L-AI. The circles icons represent the crude enzyme which was broken by ultrasonic. And the square icons represent the enzyme in bacteria suspension.

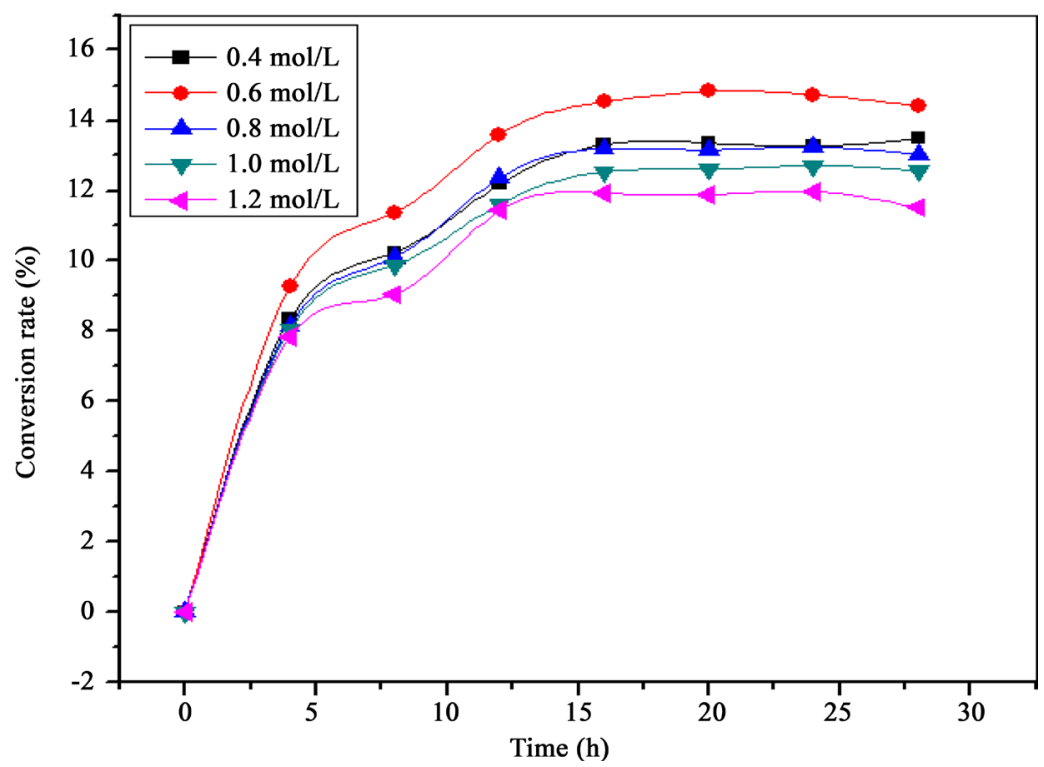

Figure 18. The effects of substrate concentration on conversion reaction of crushing coarse enzyme liquid of $L$. lactis NZ9000/pRNA48-L-AI. The square icons, circles icons, the triangle icons, the inverted square icons and the triangle icons on side represent the substrate concentration which is $0.4 \mathrm{~mol} / \mathrm{L}, 0.6 \mathrm{~mol} / \mathrm{L}, 0.8 \mathrm{~mol} / \mathrm{L}, 1.0 \mathrm{~mol} / \mathrm{L}$ and $1.2 \mathrm{~mol} / \mathrm{L}$ in the mediums of crushing coarse enzyme liquids respectively.

activity in suspending liquid will be influenced by various metal ions and EDTA under the condition of $50^{\circ} \mathrm{C}$, $\mathrm{pH} 7.17$ and the density of D-galactose is $0.6 \mathrm{~mol} / \mathrm{L}$. Comparing with the original liquid, $\mathrm{Mn}^{2+}$ of the enzyme reaction has a certain role in promoting the reaction and the property was the same as the L-AI in the wild type and other lactobacillus [39]. However, $\mathrm{Cu}^{2+}$ and $\mathrm{Zn}^{2+}$ especially the $\mathrm{Cu}^{2+}$ and $\mathrm{Zn}^{2+}$ have the stronger inhibition function on the activity of L-AI (Figure 20). And this appearance can occur in Geobacillus pallidus and Escherichia coli $K-12$, because of the enzyme activity centers were effected and lost the activity completely [37] [40].

\section{Conclusion}

L-arabinose isomerase is the key enzyme for D-galactose isomerization of D-tagatose by biological methods. 


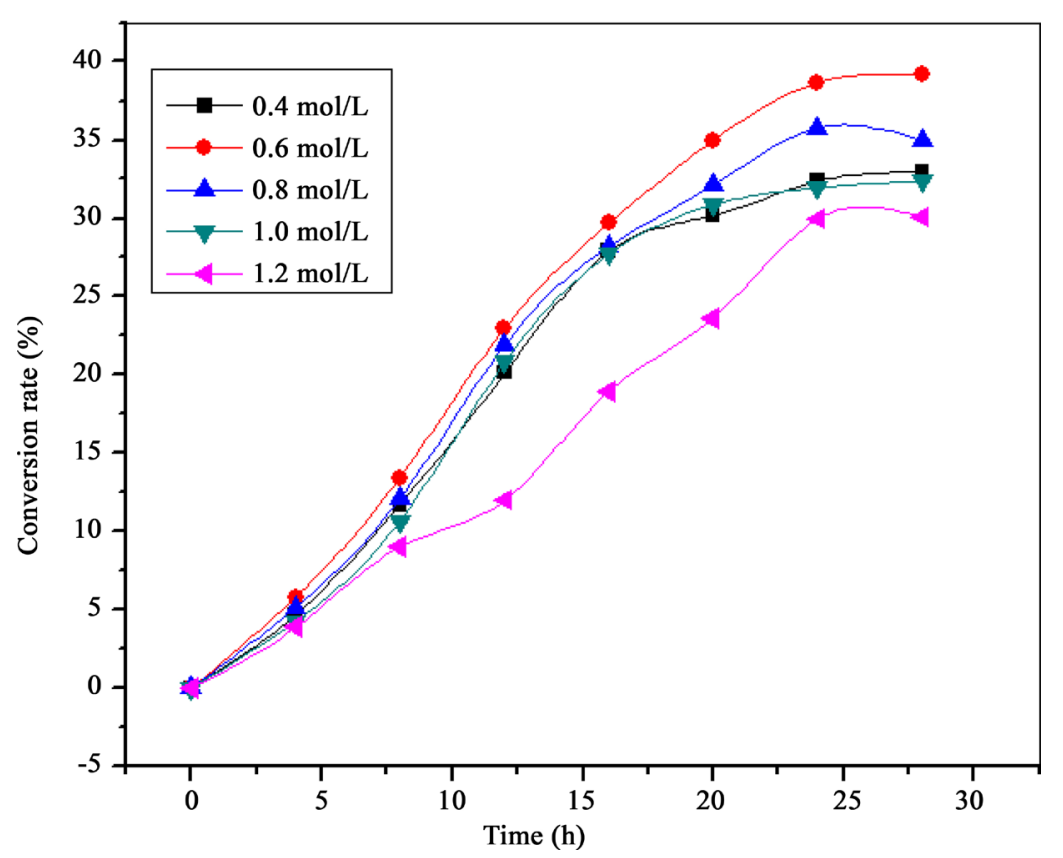

Figure 19. The effects of substrate concentration on conversion reaction of suspended bactreia liquid of L. lactis NZ9000/ pRNA48-L-AI. The square icons, circles icons, the triangle icons, the inverted square icons and the triangle icons on side represent the substrate concentration which is $0.4 \mathrm{~mol} / \mathrm{L}, 0.6 \mathrm{~mol} / \mathrm{L}, 0.8 \mathrm{~mol} / \mathrm{L}, 1.0 \mathrm{~mol} / \mathrm{L}$ and $1.2 \mathrm{~mol} / \mathrm{L}$ in mediums of crushing coarse enzyme liquids respectively.

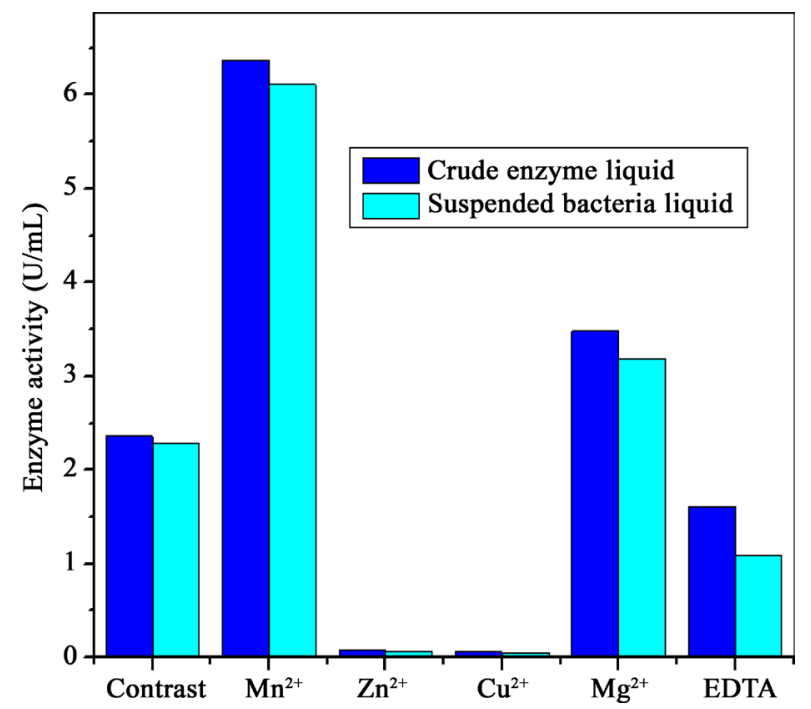

Figure 20. Effect of various metallic ions and EDTA on L-AI L. lactis NZ9000/ pRNA48-L-AI activity. The azury bars represent suspended bactreia liquid and the dark blue bars represent crushing coarse enzyme liquid.

Paper chromatography and modified cysteine carbazole sulphuric-acid method were used to screen lactic acid bacteria for high yield of D-tagatose from the separation of a number of lactic acid bacteria from pickled vegetables and pickled cabbage. In this research, we indicated that the new lactobacillus L. plantarum WU14 from pickled vegetables would be suitable for the industrial production of D-tagatose to improve yields and reduce the production costs, and this study could lay the foundation for the bioconversion D-tagatose of industrial production.

\section{Acknowledgements}

This work was supported by the National Natural Science Foundation of China (31360372), Nanchang Tech- 
nology bureau and Jiangxi Technology R\&D Program (20142BBG70015).

\section{References}

[1] Levin, G.V. (2002) Tagatose, the New GRAS Sweetener and Health Product. Journal of Medicinal Food, 5, $23-36$. http://dx.doi.org/10.1089/109662002753723197

[2] Livesey, G. and Brown, J.C. (1995) D-Tagatose Is a Bulk Sweetener with Zero Energy Determined in Rat. Journal of Nutrition, 126, 1601-1609.

[3] Donner, T.W., Wilber, J.F. and Ostrowski, D. (1999) D-Tagatose, a Nove1 Hexose: Acute Effects on Carbohydrate Tolerance in Subjects with and without Type 2 Diabetes. Diabetes, Obesity and Metabolism, 1, 285-291. http://dx.doi.org/10.1046/j.1463-1326.1999.00039.x

[4] Normen, L., Laerke, H.N., Jensen, B., et al. (2001) Small-Bowel Absorption of D-Tagatose and Related Effects on Carbohydrate Digestibility: Anileostomy Study. American Journal of Clinical Nutrition, 73, 105-110.

[5] Kim, P. (2004) Current Studies on Biological Tagatose Production Using L-Arabinose Isomerase: A Review and Future Perspective. Applied Microbiology and Biotechnology, 65, 243-249. http://dx.doi.org/10.1007/s00253-004-1665-8

[6] Manjasetty, B.A. and Chance, M.R. (2006) Crystal Structure of Escherichia coli L-Arabinose Isomerase (ECAI), the Putative Target of Biological Tagatose Production. Journal of Molecular Biology, 360, 297-309. http://dx.doi.org/10.1016/j.jmb.2006.04.040

[7] Buemann, B., Toubro, S., Raben, A., Blundell, J. and Astrup, A. (2000) The Acute Effect of D-Tagatose on Food Intake in Human Subjects. The British Journal of Nutrition, 84, 227-231.

[8] Ibrahim, O.O. and Spradlin, J.E. (2000) Process for Manufacturing D-Tagatose USA. US Patent, 6057135.

[9] Beadle, J.R., Saunder, J.P. and Wajada, T.J. (1992) Process for Manufacturing Tagatose. US Patent, 5078796.

[10] Izumori, K. and Tsuzaki, K. (1988) Production of D-Tagatose from D-Galactitol by Mycobacterium smegmatis. Journal of Fermentation Technology, 66, 225-227. http://dx.doi.org/10.1016/0385-6380(88)90052-0

[11] Izumori, K., Miyoshi, T., Tokuda, S. and Yamabe, K. (1984) Production of D-Tagatose from Ducitol by Arthrobacter globiformis. Applied and Environmental Microbiology, 46, 1055-1057.

[12] Muniruzzanman, S., Tokunaga, H. and Izumori, K. (1994) Isolation of Enterobacter Agglomerans Strain 221e from Soil, a Potent D-Tagatose Producer from Galactitol. Journal of Fermentation and Bioengineering, 78, 145-148. http://dx.doi.org/10.1016/0922-338X(94)90253-4

[13] Shimonish, T., Okumura, Y. and Izumori, K. (1995) Production of L-Tagatose from Galactitol by Klebsiella pneumoniae Strain 40b. Journal of Fermentation and Bioengineering, 79, 620-622. http://dx.doi.org/10.1016/0922-338X(95)94759-K

[14] Cheetham, P.S.J. and Wootton, A.N. (1993) Bioconversion of D-Galactose into D-Tagatose. Enzyme and Microbial Technology, 15, 105-108. http://dx.doi.org/10.1016/0141-0229(93)90032-W

[15] Manjasetty, B.A. and Chance, M.R. (2006) Crystal Structure of Escherichia coli L-Arabinose Isomerase, the Putative Target of Biological Tagatose Production. Journal of Molecular Biology, 360, 297-309. http://dx.doi.org/10.1016/j.jmb.2006.04.040

[16] Kim, B.C., Lee, Y.H. and Lee, H.S., Lee, D.W., Choe, E.A. and Pyun, Y.R. (2002) Cloning, Expression and Characterization of L-Arabinose Isomerase from Thermotoga neapolitana: Bioconversion of D-Galactose to D-Tagatose Using the Enzyme. FEMS Microbiology Letters, 212, 121-126.

[17] Oh, D.K., Oh, H.J., Kima, H.J., Cheonb, J. and Kimb, P. (2006) Modification of Optimal pH in L-Arabinose Isomerase from Geobacillus stearothermophilus for D-Galactose Isomerization. Journal of Molecular Catalysis B: Enzymatic, 43, 108-112. http://dx.doi.org/10.1016/j.molcatb.2006.06.015

[18] Oh, H.J., Kim, H.J. and Oh, D.K., (2006) Increase in D-Tagatose Production Rate by Site-Directed Mutagenesis of L-Arabinose Isomerase from Geobacillus thermodenitrificans. Biotechnology Letters, 28, 145-149. http://dx.doi.org/10.1007/s10529-005-5327-4

[19] Kim, J.W., Kim, Y.W., Roh, H.J., et al. (2003) Production of Tagatose by a Recombinant Thermostable L-Arabinose Isomerase from Thermus sp. IM6501. Biotechnology Letters, 25, 963-967. http://dx.doi.org/10.1023/A:1024069813839

[20] Jørgensen, F., Hansen, O.C. and Stougaard, P. (2004) Enzymatic Conversion of D-Galactose to D-Tagatose: Heterologous Expression and Characterisation of a Thermostable L-Arabinose Isomerase from Thermoanaerobacter mathranii. Applied Microbiology and Biotechnology, 64, 816-822. http://dx.doi.org/10.1007/s00253-004-1578-6

[21] Lee, D.W., Jang, H.J., Choe, E.A., et al. (2004) Characterization of a Thermostable L-Arabinose (D-Galactose) Isomerase from the Hyperthermophilic Eubacterium Thermotoga maritima. Applied and Environmental Microbiology, 70, 1397-1404. http://dx.doi.org/10.1128/AEM.70.3.1397-1404.2004 
[22] Rhimi, M., Juy, M., Aghajari, N., Haser, R. and Bejar, S. (2007) Probing the Essential Catalytic Residues and Substrate Affinity in the Thermoactive Bacillus stearothermophilus US100 L-Arabinose Isomerase by Site-Directed Mutagenesis. Journal of Bacteriology, 189, 3556-3563. http://dx.doi.org/10.1128/JB.01826-06

[23] Dishe, Z. and Broenfreund, E. (1951) A New Spectrophotometric Method for the Detection and Determination of Keto Sugars and Trioses. The Journal of Biological Chemistry, 192, 583-587.

[24] Weng, W.H., Zhang, H. and Jiang, B. (2006) Properties of L-Arabinose Isomerase and Biosynthesis of D-Tagatose. Science and Technology of Food Industry, 1, 158-159.

[25] Apweiler, R., Attwood, T.K., Bairoch, A., et al. (2001) The InterPro Database, an Integrated Documentation Resource for Protein Families Domains and Functional Sites. Nucleic Acids Research, 29, 37-40. http://dx.doi.org/10.1093/nar/29.1.37

[26] Mulder, N.J., Apweiler, R. and Attwood, T.K. (2005) InterPro, Progress and Status in 2005. Nucleic Acids Research, 33, D201-D205.

[27] Papagianni, M., Avramidis, N. and George, F. (2007) High Efficiency Electrotransformation of Lactococcus lactis spp. lactis Cells Pretreated with Lithium Acetate and Dithiothreitol. BMC Biotechnology, 7, 15. http://dx.doi.org/10.1186/1472-6750-7-15

[28] Siragusa, S., De Angelis, M., Calasso, M., Campanella, D., Minervini, F., et al. (2014) Fermentation and Proteome Profiles of Lactobacillus plantarum Strains during Growth under Food-Like Conditions. Journal of Proteomics, 96, 366-380. http://dx.doi.org/10.1016/j.jprot.2013.11.003

[29] Li, Y.J. (2010) Gene Cloning and Enzyme Activity Assays of L-Arabinose Isomerase. Tianjin University of Science and Technology, Tianjin.

[30] Zhang, H., Jiang, B. and Pan, B.-L. (2007) Study on Active Site of L-Arabinose Isomerase from Lactobacillus plantarum. Food Science, 28, 340-344.

[31] Mu, W.M., Zhang, T., Jiang, B. and Zhang, H. (2007) The Research Progress of D-Tagatose and L-Arabinose Isomerase. Food and Fermentation Industries, 33, 6.

[32] Zhang, G.S., Fan, M.Y., Zhang, J.M. and Cai, Y.L. (2002) Extract the Polysaccharides of Reed Rhizome. Journal of Chinese Medicine, 17, 250.

[33] Liu, Z.W., Yuan, W.J., Zhang, S.Y., Luo, J., Chen Z.L., et al. (2012) Screening and Preliminary Identification of a Lactic Acid Bacterium Strain with the Capacity of Nitrite Degradation from Sanjiang Pickled Potherb Mustard. Food Science, 33, 1.

[34] Cao, T.P., Choi, J.M., Lee, S.J., Lee, Y.J. and Lee, S.K., et al. (2014) Crystallization and Preliminary X-Ray Crystallographic Analysis of L-Arabinose Isomerase from Thermophilic Geobacillus kaustophilus. Acta Crystallographica, 70, 108-112.

[35] Xu, Z., Li, S., Feng, X.H., Liang, J.F. and Xu, H. (2014) L-Arabinose Isomerase and Its Use for Biotechnological Production of Rare Sugars. Applied Microbiology and Biotechnology, 98, 8869-8878. http://dx.doi.org/10.1007/s00253-014-6073-0

[36] Men, Y., Zhu, Y.M., Guan, Y.P., Zhang, T., Izumori, K. and Sun, Y. (2012) Screening of Food-Grade Microorganisms for Biotransformation of D-Tagatose and Cloning and Expression of L-Arabinose Isomerase. Chinese Journal of Biotechnology, 28, 592-601.

[37] Wang, D., Ding, Q.B., Ou, L., Wei, X.K., Xu, Y.M. and Sun, L.Y. (2010) Cloning and Expression of L-Arabinose Isomerase from Escherichia coli K12 and Its Application for D-Tagatose Conversion. China Food Additives, No. 5, 87-92.

[38] Cheng, L.F. (2010) Acidothermus cellulolytics L-Arabinose Isomerase: Cloning Characterization and Molecular Modification. Jiangnan University, Wuxi.

[39] Weng, W.H. (2006) Properties of L-Arabinose Isomerase and Enzymatic Preparation of D-Tagatose. Jiangnan University, Wuxi.

[40] Zhang, E. (2013) Recombinant Expression of D-Arabinose Isomerase from Geobacillus pallidus and Its Application. Jiangnan University, Wuxi. 